\title{
Mike Fitzpartick
}

\section{Mad men take over the coalition}

The popularity of the US television series Mad Men seems to have gone to the heads of senior figures in the British establishment, particularly those responsible for public health policy. Based in an advertising agency in Manhattan's Madison Avenue in the 1960s, Matthew Wiener's storylines reveal the deployment of psychological theories and techniques to sell products, such as Lucky Strike cigarettes, in ways that were first exposed in Vance Packard's famous The Hidden Persuaders. ${ }^{1}$

We Brits have long been suckers for American cultural fashions and intellectual gurus. For the former Labour government, the key figure was Martin Seligman, whose notions of 'positive psychology' and 'authentic happiness' were imported to justify early childhood intervention and parenting schemes and programmes to foster 'emotional literacy' in schools. ${ }^{2}$ Tony Blair's 'happiness Tsar', economist Richard Layard, played the role of Cliff to Seligman's Elvis. The recent announcement that David Cameron plans to introduce a measure of happiness ${ }^{3}$ into government assessments of national performance confirms the seamless continuation of this approach under the new coalition.

The latest cult US import is Chicagobased behavioural economist Richard Thaler, co-author of Nudge: Improving Decisions About Health, Wealth and Happiness, and member of the Downing Street 'Behavioural Insight Team' which reports directly to the highest levels of the civil service and the government. 4.5 The role of Cliff is now taken by David Halpern, editor of MINDSPACE: Influencing Behaviour Through Public Policy. ${ }^{6}$ These titles - vaguely sinister and slightly silly suggest some sort of comedy spoof, as though the late Leslie Nielsen had taken a role in Yes, Minister. But what is more disturbing is that these people are serious - they really believe that a combination of speculative neuroscience and pop psychology provides solutions to social and health problems.

David Cameron believes that there is 'an enormous spiritual and social hole in our country' that can be filled by his Big Society and public health initiatives. There is certainly a spiritual hole at the heart of the British establishment which has long lost any sense of direction or purpose.

But this hole will not be filled by attempts to control the behaviour of individuals. These policies are driven by the elitist presumption that people are incapable of making rational decisions and hence need expert guidance - or subliminal manipulation - to induce them to make the 'right choices', as determined by the new priesthood of behavioural psychology. Thaler's 'libertarian paternalism'4 is an oxymoron: as the drift towards increasingly coercive policies in relation to smoking, drinking and obesity confirms, the new paternalism is more authoritarian than the sternest Victorian patriarch.

Furthermore, given the marginal contribution of behaviour to most of our health problems and the lack of evidence for the efficacy of the psychological interventions being proposed, it is readily apparent that these policies will have no beneficial effects on health. Deputy prime minister Nick Clegg believes that the 'nudge' approach 'could change the way citizens think'. 'What we need is citizens thinking how to change the way that government works.

\section{REFERENCES}

1. Packard V. The Hidden Persuaders. London: Random House, 1957.

2. Seligman M. Authentic happiness: using the new positive psychology to realize your potential for positive psychology to realize your potential for
lasting fulfilment. New York, NY: Simon and Schuster, 2004.

3. David Cameron to launch 'happiness test'. London

Evening Standard 2010, 25 Nov:
http://www.thisislondon.co.uk/standard/politics/ar ticle-23900922-david-cameron-to-launchhappiness-test.do (accessed 3 Dec 2010).

4. Thaler R, Sunstein, CR. Nudge: improving decisions about health, wealth and happiness. London: Penguin, 2009.

5. Fitzpatrick M. The politics of behaviour. Br J Gen Pract 2010; 60(575): 461.

6. Institute for Government and the Cabinet Office. MINDSPACE: Influencing behaviour through public policy.

http://www.instituteforgovernment.org.uk/content /133/mindspace-influencing-behaviour-throughpublic-policy (accessed 3 Dec 2010).

7. Wintour P. David Cameron's 'nudge unit' aims to improve economic behaviour. Guardian 2010, 9 Sept:

Sept:
http://www.guardian.co.uk/society/2010/sep/09/ca meron-nudge-unit-economic-behaviour (accessed 3 Dec 2010).

DOI: 10.3399/bjgp11X549126 